\title{
Penile Cancer pTa TNM Finding v8
}

National Cancer Institute

\section{Source}

National Cancer Institute. Penile Cancer pTa TNM Finding v8. NCI Thesaurus. Code

C140062.

Penile cancer with a finding of noninvasive localized squamous cell carcinoma. (from AJCC 8th Ed.) 